\title{
Subtotální trombotická okluze vena cava superior jako komplikace kanylace centrální žily u pacienta s trombofilií
}

\author{
Roman Štípal jr.' , Ondřej Ludka' ${ }^{1}$, Viktor Musil' ${ }^{1}$,Tomáš Nebeský², Jindřich Špinar ${ }^{1}$ \\ Interní kardiologická klinika, Lékařská fakulta Masarykovy univerzity a Fakultní nemocnice Brno, Brno \\ ${ }^{2}$ Radiodiagnostická klinika, Lékařská fakulta Masarykovy univerzity a Fakultní nemocnice Brno, Brno, Česká republika
}

Adresa: MUDr. Roman Štípal jr., Interní kardiologická klinika, FN Brno, Jihlavská 20, 62500 Brno, e-mail: romanstipal@yahoo.com

Jednapadesátiletý pacient byl hospitalizován na chirurgické klinice pro ileózní stav, etiologicky šlo o akutní trombózu arteria mesenterica superior. Stav byl řešen rozsáhlou střevní resekcí od $40 \mathrm{~cm}$ aborálně za Treitzovým ligamentem

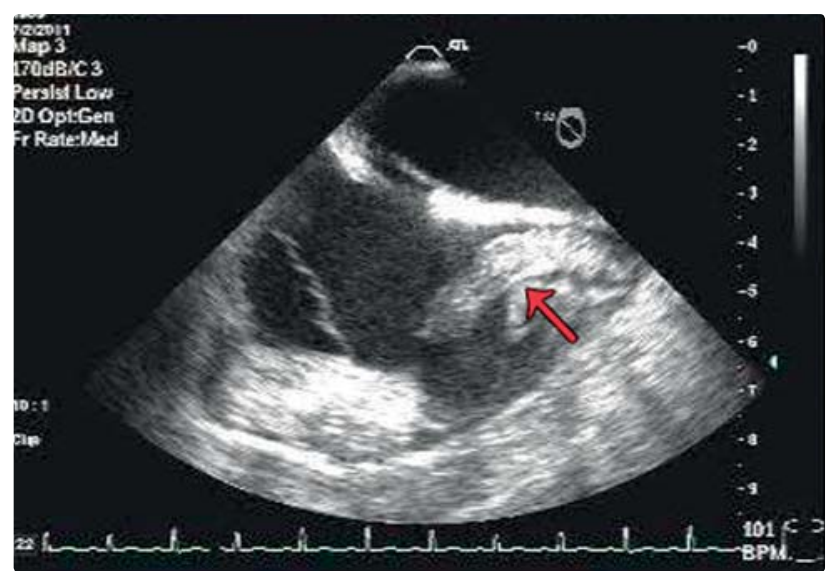

Obrázek 1 TEE obraz trombózy vena cava superior zasahující do pravé síně

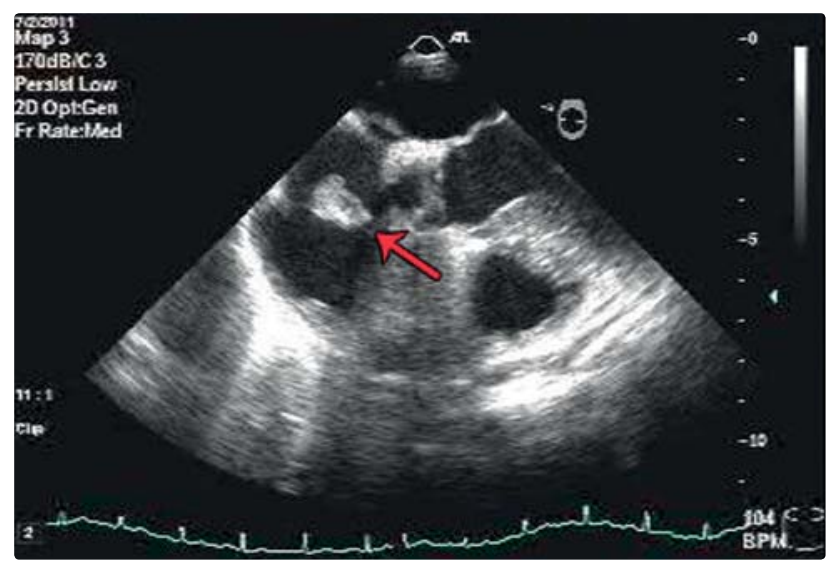

Obrázek 2 TEE obraz trombózy VCS zasahující do pravé síně příčný řez po hepatální flexuru colon a našitím jejuno-transverzoanastomózy. V rámci došetřování stavu byl zjištěn trombofilní stav, dále pozitivita glykoproteinu anti- $\beta_{2}$, heterozygocie pro faktor V Leiden a homozygocie faktoru PAI-1. Pacient byl dosud bez anamnézy trombózy či trombembolické nemoci $\mathrm{v}$ jakékoli lokalizaci. Přibližně po čtrnácti dnech po operaci byl $\mathrm{z}$ důvodu těžké malnutrice při syndromu krátkého střeva po rozsáhlém resekčním výkonu následně přeložen k další terapii do péče Interní gastroenterologické kliniky Fakultní nemocnice Brno. Pro protrahovaný septický stav byl nadále léčen antibiotiky, pro nutnost parenterální výživy měl zaveden centrální žilní katetr cestou vena subclavia dextra, během hospitalizace podávána antikoagulační léčba nízkomolekulárním heparinem (LMWH) v terapeutické dávce. $Z$ důvodu opakovaných septických špiček se pátralo po infekčním fokusu, $\mathrm{v}$ rámci došetřování provedeno transthorakální a následně transezofageální echokardiografické vyšetření, při němž byl zjištěn trombus v pravé síní vycházející z vena cava superior (obrázky 1 a 2). Pravo-levá komunikace na úrovní srdečních oddílů nebyla při Valsalvových

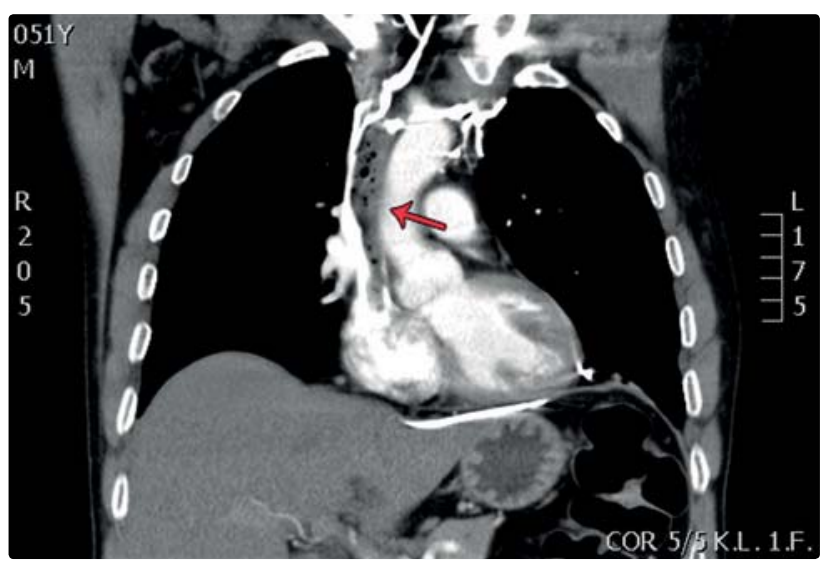

Obrázek 3 Subtotální trombóza VCS zasahující do pravé síně s patrným kolaterálním oběhem ve frontální projekci 


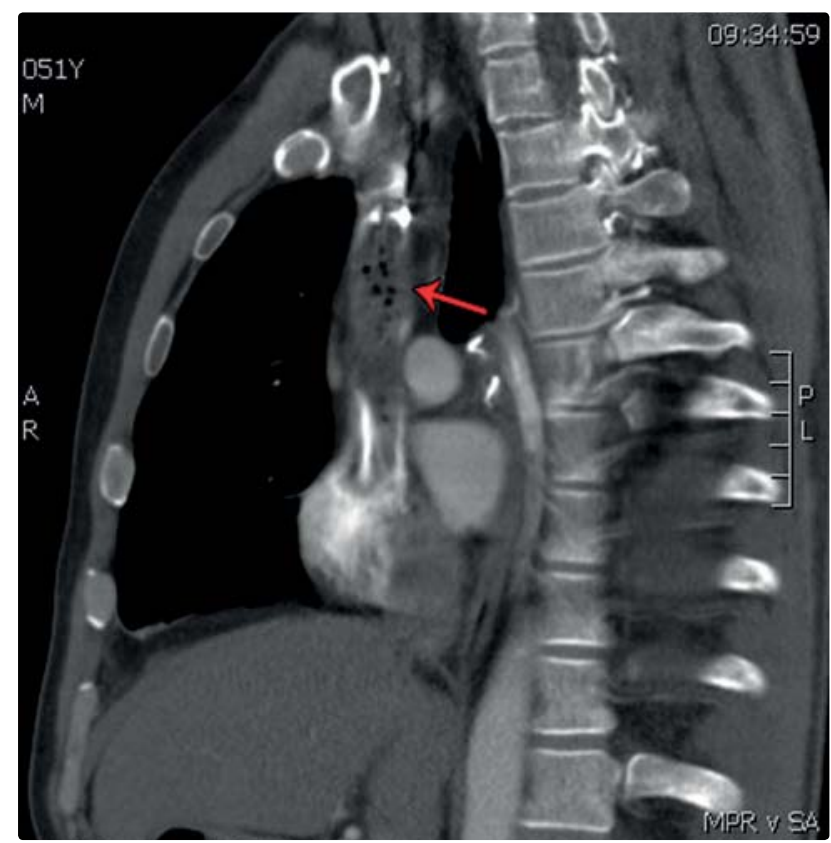

Obrázek 4 Subtotální trombotická okluze vena cava superior v sagitální projekci

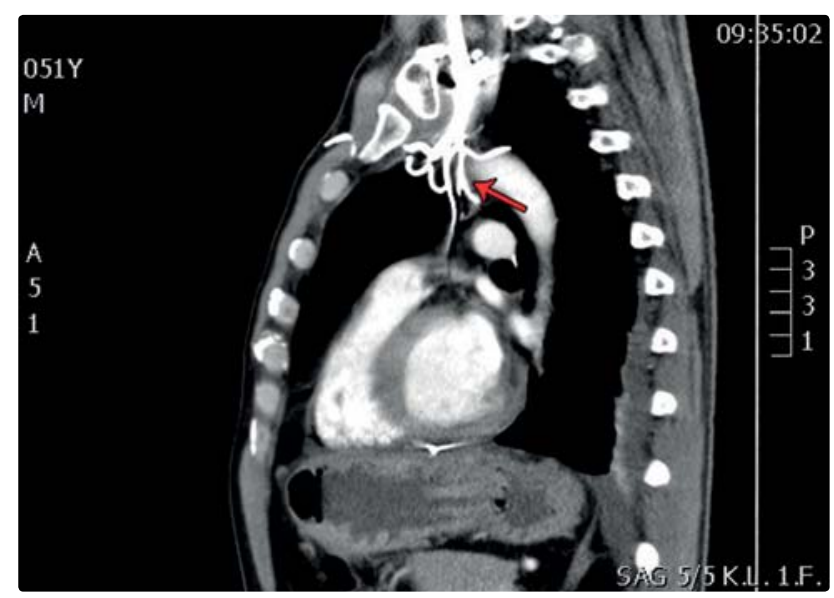

Obrázek 5 Mnohočetný kolaterální oběh v sagitální projekci

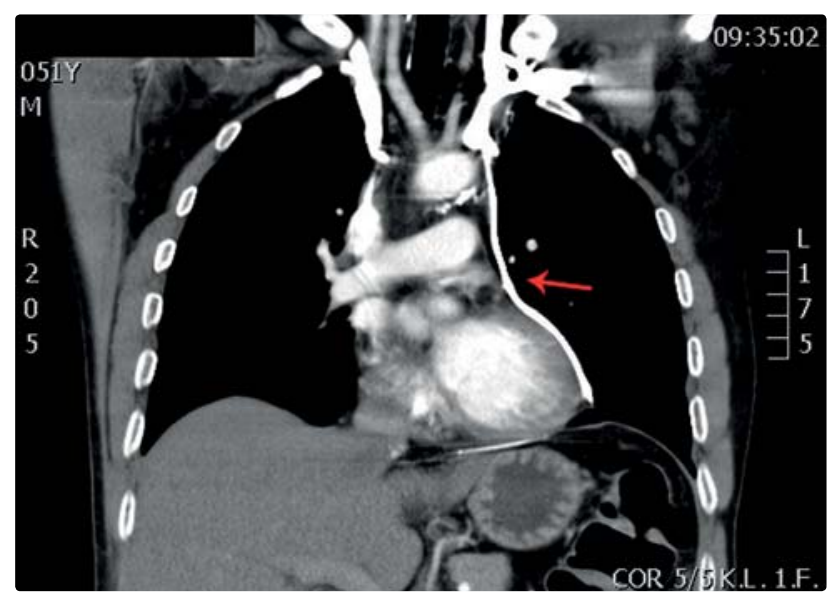

Obrázek 6 Mohutné kolaterály v oblasti perikardu a bráničních žilních pletení

manévrech ani po podání echokonstrastní látky prokázána. Byla doplněna CT angiografie potvrzující subtotální trombózu horní duté žíly, trombus zasahuje do stropu pravé síně (obrázky 3 a 4), vena brachiocephalica dextra et sinistra takřka totálně trombotizované, přítomen mnohočetný kolaterální oběh (obrázky 5 a 6). Pacient byl přeložen do Centra kardiovaskulární a transplantační chirurgie Brno, kde byla provedena trombektomie s nálezem částečně organizovaného trombu. Pooperační průběh byl nekomplikovaný, byla zahájena warfarinizace a šestý den po výkonu byl pacient předán zpět do péče Interní gastroenterologické kliniky FN Brno, kde se pokračovalo v nutriční podpoře a snaze o optimální nastavení antikoagulační terapie. Vzhledem k nekonstantnímu vstřebávání warfarinu při těžkém postižení gastrointestinálního traktu došlo k opakovaným výkyvům hodnot protrombinového času, proto po dohodě s hematologem byla u pacienta indikována doživotní antikoagulační léčba subkutánně podávaným nízkomolekulárním heparinem.

Došlo do redakce: 15. 5. 2011

Prijato: 20. 9. 2011 